Teologia i Moralność, volumen 14(2019), numer 2(26)

doi: 10.14746/TIM.2019.26.2.10

ORCID: 0000-0002-5167-0595

TOMASZ KRAJ

Uniwersytet Papieski Jana Pawła II w Krakowie

Wydział Teologiczny

\title{
Jak funkcjonuje moralność? Wybory moralne a wartości chrześcijańskie
}

Stosunkowo często stajemy wobec stwierdzenia, że jakaś propozycja moralna jest sprzeczna $\mathrm{z}$ wartościami chrześcijańskimi. Kiedyś (choć $\mathrm{w}$ dalszym ciągu problemy te zachowują aktualność) mówiło się dużo o zapłodnieniu in vitro (IVF - od ang. in vitro fertilization) czy o związkach partnerskich. Ostatnio najwięcej wspomina się o ideologii gender i LGBT. Dlatego po raz kolejny można usłyszeć, że tych propozycji nie da się pogodzić z wartościami chrześcijańskimi. Co więc znaczą owe wartości chrześcijańskie? Dlaczego nie da się z nimi pogodzić pewnych propozycji i dlaczego wartości te są tak ważne, by je bronić? Odpowiedź na te pytania nastręcza trudności, między innymi tym, którzy w dziedzinie moralnej są bardziej praktykami (czyli w swym codziennym życiu pozostają wierni owym chrześcijańskim wartościom) niż teoretykami. Pozostają wierni wartościom, ale trudność sprawia im ich obrona, umiejętność wyjaśnienia sobie i innym, dlaczego tak właśnie, a nie inaczej należy postępować. Natomiast zwykle druga strona sporu, czyli propagatorzy i zwolennicy zmian moralnych (odnoszących się np. do ludzkiej płciowości), też powołuje się na jakąś lub jakieś wartości albo zbliżone do chrześcijaństwa (np. tolerancji), albo wprost zaczerpnięte z niego, nie ukrywając przy tym, że ich celem jest odrzucenie chrześcijaństwa i kultury chrześcijańskiej i zmiana otaczającego nas świata (por. Kania 2019, s. 6-9; Nykiel 2019, s. 22-25). Specyfika tego konfliktu sprawia, że tym trudniej jest zrozumieć wystąpienia hierarchów Kościoła, którzy w imię obrony chrześcijaństwa zdają się negować przynajmniej którąś z wartości chrześcijańskich. Tak było przedstawiane wystąpienie ks. abpa Jędraszewskiego, który występując przeciw ideologii 
LGBT, został posądzony o sianie nienawiści, a więc o postawę wprost antychrześcijańską ${ }^{1}$.

Celem tego opracowania jest ukazanie pewnych prawideł, którymi rządzi się życie moralne każdego człowieka, a więc także życie chrześcijańskie, oraz na czym polega specyfika wartości chrześcijańskich i co to znaczy, że jakaś propozycja moralna jest sprzeczna z wartościami chrześcijańskimi. Cel ten zostanie osiągnięty, gdy chrześcijański Czytelnik będzie wiedział, w jaki sposób może bronić swej postawy i swojej wiary, stając wobec często agresywnych współczesnych ideologii i ich propozycji.

\section{Moralność: jej funkcjonowanie a wyjaśnienie tego funkcjonowania}

Pierwszym zagadnieniem, które należy poruszyć, jest bardzo ważne rozróżnienie na funkcjonowanie moralności (czyli że ludzie dokonują moralnych wyborów i jak to się odbywa) oraz wyjaśnienie tego funkcjonowania (czyli dlaczego to przebiega tak, a nie inaczej, oraz kwestia uzasadnienia danego wyboru; por. Rhonheimer 1994, s. 25). Wielu ludzi sprawnie dokonuje wyborów moralnych, natomiast ma problem z wyjaśnieniem, dlaczego dokonuje takich właśnie, a nie innych wyborów. Dlatego pierwsza część tego opracowania będzie dotyczyć samych wyborów moralnych, druga natomiast będzie wyjaśnieniem, dlaczego takich właśnie, a nie innych wyborów dokonują i/lub winni dokonywać.

Żyjąc w świecie i rozwijając swoją osobowość, angażujemy się w wiele działań i odniesień: do Boga, innych ludzi czy także siebie samego (samej), poprzez świadome i dobrowolne wybory, pozostające $\mathrm{w}$ relacji do dobra i zła. Jeśli wybory, na które napotykamy w życiu dorosłym, pokrywają się z tymi, których dokonywali nasi rodzice albo których dokonywaliśmy, zyskując ich aprobatę, to nie ma większego problemu. Trudności zaczynają się pojawiać, gdy spotykamy sytuacje nowe, nowe propozycje, które podsuwa nam świat: współmałżonek, kolega lub koleżanka z pracy, znajomy, osobowość z mediów (celebryta), moja grupa w ramach naszej aktywności na portalach społecznościowych itp. Mniej pewnie czujemy się zwłaszcza wtedy, gdy te nowe propozycje stają w opozycji do wyborów dokonywanych wcześniej; gdy stają się one dla nas wyzwaniem, bo na przykład wiążą się z burzliwą debatą społeczną czy z różnego rodzaju ekscesami (np. jako bunt wobec dotychczasowych wartości wyrażany poprzez bluźnierstwo, profanację czy fizyczną agresję). Wtedy

\footnotetext{
${ }^{1}$ Por. m.in. Anon, Senator Pociej o abpie Jędraszewskim i "tęczowej zarazie": Jako głos PO mówię, że to skandaliczne stowa, http://www.tokfm.pl/Tokfm/7,103087,25053883, senator-pociej-a-abp-jedraszewskim-i-teczowej-zarazie-jako.html, [dostęp: 27.08.2019].
} 
mogą pojawiać się wątpliwości i chcielibyśmy dokładnie wiedzieć, jakie naprawdę wartości wchodzą $\mathrm{w}$ grę, ewentualnie jak bronić własnego stanowiska, dotychczasowej postawy.

Takie dylematy rodzą się dziś w Polsce, szczególnie w kontekście propozycji związanych z ideologią gender. Pojawia się propozycja mówiąca, że możemy sobie dowolnie określić własną płeć i wybrać nową rolę, jaką chcielibyśmy odgrywać w społeczeństwie. Jeśli czujemy się zmęczeni i sfrustrowani dotychczasowym życiem, a dowiadujemy się, że właściwie cały zachodni świat już myśli w przedstawiany nam sposób, to zaczynają się rodzić poważne wątpliwości. Ci, którzy te propozycje podsuwają, twierdzą, że jest to nowa, wyższa (a więc lepsza) forma wyrazu naszej wolności i tożsamości. $Z$ drugiej strony słyszymy, że nie wszystko jest takie optymistyczne; że jest opór wobec tych propozycji, a nade wszystko, że są one sprzeczne z wartościami chrześcijańskimi.

W ramach dyskusji na temat wielu współczesnych propozycji moralnych, niekoniecznie dotyczących ludzkiej seksualności (może to być także problem autonomii osoby i związanego z nią subiektywizmu, problem sprawiedliwości społecznej w kontekście pretensji pewnych grup do bycia elitą i posiadania z tego tytułu rozlicznych przywilejów), pojawia się stwierdzenie, że przecież Pismo Święte, na które powołuje się Kościól, nic nie mówi o gender; nic też nie mówi o IVF, o którym tyle się ostatnio wspominało. Jest co prawda nauczanie Magisterium Kościoła, będące komentarzem do Pisma Świętego, ale nawet $\mathrm{w}$ tym przypadku w jakimś tam okresie, nieraz bardzo długo, nie można było znaleźć w tymże nauczaniu żadnych wskazań co do gender i IVF. Problem ten nie dotyczy tylko tych dwóch zagadnień. Także współczesna biotechnologia z jej spektakularnymi osiągnięciami proponuje coraz to nowsze rozwiązania, dla których trudno znaleźć definitywne rozstrzygnięcie w moralnym nauczaniu Kościoła. Co wtedy ma zrobić chrześcijanin: Co ma wybrać i na podstawie czego, jakich racji?

Problem ten (braku konkretnych wskazań w nauczaniu Kościoła) rozwiązuje nam prawo naturalne. Prawo to, zgodnie z jego klasyczną definicją, jest udziałem ludzkiego rozumu w odwiecznym prawie Bożym. Człowiek dzięki temu, że ma rozum, jest w stanie dokonać rozróżnienia między tym, co moralnie dobre, co przyczynia się do jego dobra i rozwoju, a tym, co staje się przeszkodą na tej drodze. Dzięki prawu naturalnemu człowiek wie, co jest dobre, a co złe, i co powinien wybrać, a czemu się sprzeciwić. Może ktoś zapytać: A jak ktoś nie zna prawa naturalnego? Nie ma takiej możliwości. Każdy bowiem człowiek stworzony jest przez Boga i ma rozumną duszę. Dzięki niej ma on, przynajmniej w stopniu podstawowym² ${ }^{2}$, zdolność rozróżniania dobra

\footnotetext{
2 Umiejętność rozróżniania dobra i zła określana tu jako podstawowa, dotyczy zagadnienia zróżnicowania norm prawa naturalnego. Prawo to ma trzy rodzaje (stopnie) norm: normy najbar-
} 
i zła. Dlatego nikt nie może powiedzieć, że nie spotkał się jeszcze z tym prawem, bo jeszcze o nim nie słyszał albo nie doczytał ${ }^{3}$. Prawo naturalne funkcjonuje bowiem w taki sposób, że pojawia się ono w momencie, gdy człowiek staje wobec wyboru moralnego (por. May 2003, s. 74) ${ }^{4}$. Dzięki temu prawu w większości swoich życiowych sytuacji człowiek wie, co powinien zrobić, jakiego wyboru dokonać. Może on nie wiedzieć, jak ten wybór (później) uzasadnić, ale to, co ma zrobić, by być w zgodzie ze swoim sumieniem, zwykle wie. Na przykład, rodzice doskonale wiedzą, że aborcja jest czymś złym. Mają tego świadomość, szczególnie gdy stają wobec wyboru związanego z aborcją. Nie oznacza to jednak, że każdy z rodziców, biorąc pod uwagę współczesne zamieszanie $\mathrm{w}$ tym względzie, jest $\mathrm{w}$ stanie kompetentnie wyjaśnić, dlaczego to jest zło. To są dwa różne aspekty tego samego wyboru: wiedzieć o tym, co zrobić, i umieć swój wybór kompetentnie uzasadnić. To pierwsze z reguły wiedzą wszyscy, to drugie już niekoniecznie. Wielu małżonków zdaje sobie sprawę, że antykoncepcja jest złem. Nieliczni spośród nich potrafią wyjaśnić, dlaczego to jest zło. Dlatego do dokonania wyboru moralnego wystarczy nasza wiedza, że coś jest złe i że nie powinniśmy tego robić i prawo naturalne w łączności z głosem naszego sumienia w znacznej większości sytuacji zadośćczyni temu wymogowi w sposób całkowicie satysfakcjonujący. Nie rozumiejąc tej różnicy - między wiedzą o tym, co dobre i złe, a umiejętnością wyjaśnienia, dlaczego to jest dobro lub zło - wielu ludzi sądzi, że dopóki ktoś ich nie przekona, dlaczego coś jest moralnie złe, tzn. dopóki ktoś im nie wyjaśni tego, a oni tego wyjaśnienia nie zaaprobują, dopóty mogą się czuć zwolnieni z obowiązku unikania danego zła i wybierania dobra. Wielu ludzi myślących w ten sposób nie chce przy tym słuchać ani nie chce podejmować żadnego wysiłku, by zrozumieć, dlaczego ich postępowanie jest złe, i myśli, że taka postawa usprawiedliwia ich złe wybory ${ }^{5}$.

Jeśli więc prawo naturalne działa zawsze, to dlaczego są ludzie, którzy jednak postępują wbrew temu prawu; dlaczego jest tyle wykroczeń moralnych, skoro to prawo jest i działa, nawet jeśli ludzie nie rozumieją mecha-

dziej podstawowe, normy im bliskie oraz normy dalsze. Każdy człowiek dysponujący normalnym używaniem rozumu jest w stanie rozpoznać normy najbardziej podstawowe, a dzięki wychowaniu, o jakim mówimy w kulturze polskiej, także normy im bliskie (np. Dekalog), a niektórzy są w stanie rozpoznać także normy dalsze, do czego potrzeba zarówno pewnych uzdolnień moralnych w postaci specyficznych cnót, jak i wiedzy, często specjalistycznej (May 2003, s. 76-80). Mogą też istnieć przeszkody w tym rozeznaniu, z których najczęstszymi są zła wola i przywiązanie do złego.

3 Takie stwierdzenie można porównać do twierdzenia, że żadne małe dziecko nie zetknęło się jeszcze $\mathrm{z}$ tlenem, bo nie wie, co to tlen.

${ }^{4}$ Dzięki specyficznemu uzdolnieniu, jakim jest indywidualne ludzkie sumienie, człowiek reaguje (bardziej lub mniej) na wskazania tego prawa.

${ }^{5}$ Brak chęci dowiedzenia się i zrozumienia, dlaczego coś jest złe, nie jest oczywiście jedynym powodem, dla którego ludzie czynią zło. 
nizmu jego działania? $\mathrm{Na}$ to pytanie można odpowiedzieć innym pytaniem: Dlaczego dzieci nie słuchają swoich rodziców, i to nawet wtedy, gdy wiedzą, że rodzice chcą czegoś dla ich dobra; że to, co jest nieposłuszeństwem wobec rodziców, jest złem? Są bardzo różne powody, dla których ludzie wybierają zło, często wbrew wyraźnemu głosowi własnego sumienia, które jest głosem Boga w ich sercu: zła wola, złe przyzwyczajenia (nałogi), niewiedza (często zawiniona), strach, pycha, chęć podkreślenia własnej autonomii, chęć walki z Bogiem i ustanowionym przez Niego porządkiem (np. Dekalogiem), nienawiść, głupota, uprzedzenia i wiele innych ${ }^{6}$.

\section{Uzasadnienie wyboru moralnego}

Wiedząc, że wybór moralny, stanowiący sedno moralności, ma dwa istotne aspekty, teologia moralna koncentruje się nie tylko na samym wyborze (jego warunkach i tym jak on się dokonuje), ale także na jego uzasadnieniu. Jest ono związane $\mathrm{z}$ pewnym opisem świata i człowieka w nim żyjącego, czyli z jakąś antropologią. Jej istotną częścią są pewne wartości, które na swej drodze napotyka człowiek. Wobec ścierania się różnych wizji antropologicznych i związanego z tym zamieszania teologia moralna szuka sposobów dotarcia do współczesnego człowieka, również tego, który żyje obecnie w Polsce, gdzie, głównie za przyczyną mass mediów, zaczynają występować podobne zjawiska, jak w całym zachodnim świecie. Jednym z tych zjawisk jest utrata wrażliwości na Boga i Jego prawo, co bardzo trafnie zauważa między innymi papież emeryt Benedykt XVI ${ }^{7}$. Dlatego teologia, także teologia moralna, musi szukać odpowiedniego sposobu przedstawienia własnych racji, które nie tylko będą przemawiały do dzisiejszego człowieka, ale też będą dla niego przekonujące.

$\mathrm{Z}$ tego powodu trudno odwoływać się do argumentacji teologicznej w ścisłym tego słowa znaczeniu, tzn. do tego, co mówi Pismo Święte, Tradycja czy, również należące do niej, współczesne nauczanie Magisterium. Wybrany w tym opracowaniu sposób jest propozycją będącą w znacznej mierze odpowiedzią na zarzut, że opieranie się głównie albo wyłącznie na argumentacji teologicznej uniemożliwia nam dotarcie do ludzi, dziś także niektórych członków Kościoła, którzy z myśleniem i argumentacją teologiczną nie mają zbyt wiele do czynienia: po prostu tego rodzaju argumentacji nie znają lub z jakichś

\footnotetext{
${ }^{6}$ Zagadnieniami tymi w sposób dogłębny zajmuje się etyka ogólna i teologia moralna fundamentalna.

${ }^{7}$ Benedykt XVI zauważa, że „w społeczeństwie zachodnim Bóg jest nieobecny i nie ma nic do powiedzenia" - Anon, Benedykt XVI skomentowat reakcje na jego tekst o przyczynach pedofilii w Kościele, https://www.tvp.info/44116463/benedykt-xvi-skomentowal-reakcje-na-jego-tekst-oprzyczynach-pedofilii-w-kosciele [dostęp: 30.08.2019].
} 
powodów jej nie podzielają ${ }^{8}$ Z $\mathrm{Z}$ drugiej strony należy się bronić przed zarzutem odejścia od argumentów teologicznych, co miałoby prowadzić do utraty własnej tożsamości i być tego przejawem. Dlatego klucza do rozwiązania tego dylematu najlepiej poszukać w definicji teologii moralnej.

Istnieje wiele definicji teologii moralnej, spośród których kilka przedstawia ks. prof. Ireneusz Mroczkowski w swym opracowaniu Teologia moralna. Definicja. Przedmiot. Metoda (por. Mroczkowski 2011). Jedną z nich jest definicja Servaisa Th. Pinckaersa zaczerpnięta z jego przetłumaczonego na język polski dzieła Źródła moralności chrześcijańskiej: „Teologia moralna jest częścią teologii, która rozpatruje ludzkie czyny, aby je przyporządkować miłującej wizji Boga będącej prawdziwym i pełnym szczęściem oraz celowi ostatecznemu człowieka, za pośrednictwem łaski, cnót i darów, a to w świetle Objawienia i rozumu"9. Autorami innej definicji są profesorowie z Papieskiego Instytutu Jana Pawła II dla Studiów nad Małżeństwem i Rodziną w Rzymie. Mówi ona, że teologia moralna jest refleksją obejmującą „,dynamizm działania chrześcijańskiego, rozumianego jako odpowiedź na początkowe (źródłowe) wezwanie Ojca do wypełnienia (spełnienia) obrazu Bożego i bycia synami w Synu, poprzez współdziałanie łaski i wolności ludzkiej, pod kierunkiem Ducha Świętego"10. Ireneusz Mroczkowski podaje także swoją własną definicję teologii moralnej:

Teologia moralna jest nauką teologiczną, która analizuje, ocenia i wyjaśnia postępowanie człowieka, znajdującego w Bogu Ojcu Źródło Życia, w Jezusie Chrystusie Drogę do celu i w Duchu Świętym inspirację do miłości. Teologia moralna korzysta z wiary i rozumu w wyjaśnianiu biologicznych, psychicznych i duchowych uwarunkowań chrześcijanina żyjącego we wspólnocie Kościoła (Mroczkowski 2011, s. 22).

\footnotetext{
${ }^{8}$ Padające tu stwierdzenia wymagają pewnego komentarza, dopowiedzenia. Kościół poprzez swoich pasterzy ma prawo głosić takie nawet rzeczy, których ludzie niewierzący nie rozumieją lub które wydają się im dziwne albo niestosowne. Jest to bowiem słowo skierowane do wyznawców Chrystusa, do ludzi wezwanych i obdarzonych łaską. Występując w imieniu Chrystusa, pasterze mają nie tylko prawo, ale także obowiązek głosić i przypominać o Jego wymaganiach w dzisiejszym świecie. Fakt, że wielu ludzi niebędących członkami Kościoła, mając dziś dostęp do tego przepowiadania, może się czuć zgorszonymi, nie jest żadną racją, dla której pasterze mogliby się wstrzymywać od mówienia lub modyfikować owo przepowiadanie. Użycie w przepowiadaniu środków wyrazu zaczerpniętych ze „świata” nie jest tym samym, co dostosowywanie treści przepowiadania do tego ,świata".

9 S.Th. Pinckaers, Źródła moralności chrześcijańskiej, Poznań 1994, s. 32 (Mroczkowski 2011, s. 22).

${ }^{10}$ L. Melina, J. Noriega, J.J. Perez-Soba, Camminare nella Luce dell'Amore. I fondamenti della morale cristiana, Siena 2008 (Mroczkowski 2011, s. 22).
} 
Obok tych bardzo ważnych i trafnych definicji I. Mroczkowski przytacza jeszcze jedną, która zwraca na siebie szczególną uwagę nie tylko dlatego, że jej autorem jest Jan Paweł II, a sama definicja zawarta jest w encyklice Veritatis splendor. Jest ona szczególnie ważna, ponieważ mówi, z jakiej podstawowej perspektywy oceniane jest ludzkie postępowanie. Ta perspektywa wyznacza też sposób argumentacji, który we współczesnym zlaicyzowanym świecie zachowuje znaczną siłę przekonującą. Jest to perspektywa dobra i zła.

Teologia moralna jest refleksją, która dotyczy „moralności” czyli dobra i zła ludzkich czynów oraz osoby, która ich dokonuje, i w tym sensie jest otwarta na wszystkich ludzi; ale jest także „teologią”, jako że za początek i cel moralnego działania uznaje Tego, który „Jeden jest tylko Dobry” i który ofiarowując się człowiekowi w Chrystusie, obdarza go szczęściem Boskiego życia ${ }^{11}$.

Jak dalej zauważa Mroczkowski, charakterystyczną cechą tej definicji teologii moralnej jest jej wyczulenie na współczesny dyskurs etyczny. Uwzględnia ona fakt, że dyskurs ten prowadzony jest między innymi w nowych dziedzinach teologii moralnej takich, jak bioetyka czy moralność małżeńska oraz że jest prowadzony także z ludźmi, którzy nie są przekonani do racji prezentowanych ani przez Magisterium, ani nawet w ramach chrześcijańskiej wizji ludzkiego życia (chrześcijańskiej antropologii). Także wielu chrześcijan i katolików, żyjąc we współczesnym świecie i spotykając różnego rodzaju, lecz głównie achrześcijańskie lub antychrześcijańskie naświetlenia rozmaitych zagadnień moralnych, jest skłonnych z różnych powodów, na przykład presji społecznej i medialnej, uznać je za swoje. Mamy do czynienia z dużą liczbą ludzi nienależących do Kościoła i z postępującą laicyzacją wśród wyznawców Chrystusa, której efektem jest specyficzny, często mało chrześcijański sposób myślenia i wartościowania. Obok nich dość często spotykamy różne osobowości, na przykład w gronie polityków, chcących, pomimo wszystko, zachować wierność Kościołowi i jego nauczaniu. Powołują się oni na wartości chrześcijańskie, ale widać, że sprawia im to wielką trudność albo nie są w stanie wyjaśnić, co wówczas mają na myśli. Dlatego często są postrzegani jako ludzie, którzy w sposób nierozumny sprzeciwiają się zmianom kulturowym i cywilizacyjnym. Ów brak znajomości pewnych podstawowych racji, jakieś intelektualne wyjałowienie, sprawia, że coraz więcej ludzi wierzących nie jest w stanie spełnić wymogu, o którym mówił św. Piotr Apostoł, by być gotowym „do obrony wobec każdego, kto domaga się od was uzasadnienia tej nadziei, która w was jest" (1 P 3,15).

11 Jan Paweł II, Encyklika Veritatis splendor, nr 29 (Mroczkowski 2011, s. 21). 
Z podobną sytuacją musiał się zmierzyć św. Paweł w czasie swej pracy apostolskiej. Tamte warunki także wymagały specyficznych form przekazu, co zauważa św. Paweł w Pierwszym Liście do Koryntian: „A ja nie mogłem, bracia, przemawiać do was jak do ludzi duchowych, lecz jako do cielesnych, jak do niemowląt w Chrystusie. Mleko wam dałem, a nie pokarm stały, boście byli niemocni; zresztą i nadal nie jesteście mocni. Ciągle przecież jesteście cieleśni" (1 Kor 3,1-3). To Pawłowe spostrzeżenie staje się i dziś drogowskazem dla teologii, także teologii moralnej. Dlatego biorąc pod uwagę podobne doświadczenia, również dzisiaj należy zwrócić uwagę na możliwości percepcyjne adresatów chrześcijańskiego przesłania. W ramach współczesnych zagadnień moralnych oznaczać to będzie konieczność odwołania się głównie do argumentów rozumowych, a w kwestiach moralnych odwołania się przede wszystkim do kategorii dobra i zła.

Odwołanie się do argumentacji o charakterze rozumowym (filozoficznym) nie jest jednak porzuceniem argumentacji i stanowiska teologicznego. Argumentacja o charakterze rozumowym stanowi bowiem część argumentacji teologicznej. Jeśli człowiek używa swego rozumu zgodnie z jego zasadami, to używa zgodnie z jego przeznaczeniem daru otrzymanego od Boga. Bóg jest Stwórcą zarówno ludzkiego rozumu, jak i zasad jego funkcjonowania. Dlatego św. Paweł mówi pochodzącym spośród pogan chrześcijanom z Filippi o możliwości wykorzystania wszelkich humanistycznych osiągnięć ludzkiego rozumu jako czegoś wartościowego w życiu chrześcijańskim: „W końcu, bracia, wszystko, co jest prawdziwe, co godne, co sprawiedliwe, co czyste, co miłe, co zasługuje na uznanie: jeśli jest jakąś cnotą i czynem chwalebnym - to miejcie na myśli!" (Flp 4,8). W tej perspektywie użycie argumentacji rozumowej nie jest niczym innym, jak wykorzystaniem ludzkich zdolności danych nam przez Boga i przez Niego odpowiednio ukształtowanych (także w ich działaniu poznawczym), byśmy za ich pomocą dążyli do zbawienia, poznając siebie i otaczający nas świat jako drogę wiodącą ku Bogu. Tak więc, używanie argumentacji rozumowej nie sprawia, że przyjęty wywód nabiera charakteru wyłącznie filozoficznego. Argumentacja rozumowa jest bowiem częścią argumentacji teologicznej, która ze swej strony nie zatrzymuje się jedynie na tym, co nam mówi nasz naturalny rozum, lecz idzie dalej i głębiej w swych argumentach i uzasadnieniach ${ }^{12}$. Argumentacja rozumowa może natomiast być miejscem spotkania $\mathrm{z}$ ludźmi, którzy już/jeszcze nie podzielają racji teologa wyjaśniającego swoje stanowisko.

Wracając do kwestii uzasadnienia wyborów moralnych, trzeba zaznaczyć, że pierwsze z nurtujących pytań brzmi: Dlaczego prawo naturalne nakazuje takie właśnie, a nie inne wybory moralne? Dlatego, że będąc prawem moral-

12 Więcej na ten temat można znaleźć w: Abbà 2003, s. 97-127 oraz Pinckaers 1999, s. 10-20. 
nym chce zabezpieczyć dobro człowieka. Co jednak jest tym dobrem? Wiara odpowie nam, że największym dobrem jest dobro naszego zbawienia. Jednak zanim je osiągniemy, przed nami długa droga, usiana różnymi wyzwaniami, między innymi takimi, gdzie mamy do czynienia z deficytem doświadczonych nauczycieli i przewodników, bo wybór moralny coraz częściej dotyczy czegoś zupełnie nowego, wobec czego nie stawali ani nasi rodzice, ani dziadkowie, ani nawet starsi koledzy czy koleżanki (bo teraz dopiero pojawiła się możliwość IVF, dopiero teraz pojawiły się propozycje ideologii LGBT i związane z nimi pytania.). Jeśli podążę za tym, co mówi mi sumienie, szybko zorientuję się, że będzie to dążenie wbrew temu, co, przynajmniej w przekazie medialnym, uznał już prawie cały otaczający nas świat. Mój duszpasterz podpowiada mi, że mój wybór jest dobry, ale ja mam wątpliwości. Sądzę, że on tak mówi, bo tak mu każą mówić jego przełożeni. Inni też twierdzą, że Kościół jest ze swej natury konserwatywny i lepiej się czuł, gdy ludzie nie mieli takich propozycji jak dziś, więc i teraz chce jak najdłużej zachować resztki owego starego i bezproblemowego status quo, a nawet do niego powrócić. Tymczasem ludzie muszą iść z postępem. Każdy chyba to wie i rozumie. Ten rozdźwięk nie daje nam jednak spokoju, bo znamy wielu dobrych księży oraz dobrych zaangażowanych katolików mówiących to samo, co księża. Dlaczego ci księża i świeccy, a wydaje się, że i prawo moralne, na które się powołują, wskazują na te „stare" wybory jako poprawne moralnie, a nie chcą tego nowego, nie chcą ani IVF, ani ideologii gender? Dlaczego tak jest?

Dlatego, że ci ludzie i przypominane przez nich wybory prowadzą do ludzkiego dobra, a dobro to, o którym mówią, nie wydaje się jedynie jakimś ulotnym atrybutem, cechą, która dziś jest taka, a jutro inna, i wszystko zależy od tego, co zechcemy uznać za dobro dziś, a co jutro. Wydaje się, że w życiu nie ma takiej zmienności, o jakiej słyszymy w ramach ideologii gender, a ponadto że to nie my decydujemy, co jest dobre, a co złe dla człowieka. Owszem, w pewnym okresie może się wydawać, że coś jest cool, ale wiemy z doświadczeń innych ludzi, że w wielu przypadkach kontynuacja owego cool źle się dla nich skończyła. Realne życie różni się od filmu i gry komputerowej. Kontynuacja i utrwalenie pewnych wyborów zamiast obiecanego dobra zaowocowała wielkim złem ${ }^{13}$. Coś, co wydawało się dobrem, z perspektywy czasu (z pewnego dystansu) okazywało się czymś zupełnie innym. Doświadczenie, które ludzie mają w tym względzie i którym dzielą się ze swymi duszpasterzami, pozwala tym ostatnim dostrzec pewne mechanizmy (zasady) funkcjonujące

${ }^{13}$ Być może, że gdyby obietnice dobra zawsze się sprawdzały i jeśli coś, co wydawało się dobrem, zawsze się takim okazywało, to nie byłoby żadnego problemu. Wtedy także pisanie takiego opracowania byłoby czymś zbędnym. 
w przestrzeni moralnej i wypracować pewne reguły, którymi następnie pragną podzielić się z wiernymi.

Obserwacje te przypominają przede wszystkim o obiektywnym charakterze ludzkiego dobra. Dobrem niekoniecznie jest to, czego człowiek wiedziony chwilowym pragnieniem chce, lecz jest to jakaś rzeczywistość przez nas zastana. Co więcej, to nie my decydujemy, co jest dobre dla człowieka, a co nie. To jest coś, co już jest ustalone i do pomnożenia czego możemy się przyczynić albo co możemy pomniejszyć lub zniszczyć, ponosząc jednak odpowiedzialność i konsekwencje naszych wyborów i działań. Nie mamy natomiast takiej mocy sprawczej, by zło z tego tylko powodu, że zostało przez nas nazwane dobrem, dobrem się stawało i odwrotnie: by dobro nazwane przez nas złem, tylko $\mathrm{z}$ tego tytułu, że myśmy je nazwali złem, stawało się złem.

Dlatego stwierdzenie, że nie my ustalamy, co jest dla człowieka dobre, a co złe, od wieków koncentrowało ludzką uwagę na poszukiwaniu odpowiedzi na pytanie, kim jest człowiek oraz na czym polega jego dobro. Wśród licznych poglądów o charakterze filozoficznym, będących próbą odpowiedzi na te pytania, są opisy ludzkiej kondycji, które korzystają ze swego rodzaju poznawczego uprzywilejowania, jakim jest możliwość korzystania z Bożego objawienia, które potwierdza pewne ludzkie intuicje ${ }^{14}$. W tej grupie jednym $\mathrm{z}$ najbardziej przekonujących nie tylko dla osób szukających odpowiedzi na pytanie o wartości chrześcijańskie, a więc o dobro i zło jako uzasadnienie wyborów moralnych, jest opis dokonany przez św. Tomasza z Akwinu.

\section{Antropologia chrześcijańska - ujęcie rozumowe}

Kościół w swym nauczaniu moralnym stara się uzasadnić powinność moralną (wybór $\mathrm{z}$ tą powinnością zgodny) ${ }^{15}$. Nie mamy tu więc do czynienia z przekazem typu arbitralnego: ,tak i tylko tak, i koniec!” Uzasadnienie to odwołuje się do opisu ludzkiego życia, który pomaga zrozumieć wymogi dotyczące naszego postępowania. Pokazuje on zarazem, co to są i skąd się biorą owe „,wartości chrześcijańskie”, których nikomu nie wolno naruszać.

Punktem wyjścia w tym opisie jest obserwacja dotycząca ludzkiego życia, ludzkiej egzystencji, która mówi o ich dynamice. Ludzkie życie się rozwija,

${ }^{14}$ Zarówno w teologii, jak i w filozofii chrześcijańskiej mówi się przede wszystkim o ujęciu augustyńskim i tomistycznym. Wielość możliwych filozoficznych ujęć ludzkiej kondycji (w tym tego, co jest dobrem człowieka) informuje nas o tym, że poznanie człowieka jest zadaniem trudnym i wymagającym. Nie oznacza to jednak, że jest czymś niemożliwym i człowiek jest skazany na „wymyślenie" samego siebie od nowa, z czym mamy do czynienia w wielu ideologiach, m.in. w ideologii gender.

${ }^{15}$ Uzasadnienie to, jak pamiętamy, jest czymś wtórnym w stosunku do samego wyboru. 
począwszy od pierwszych momentów swego istnienia, od poczęcia, poprzez okres przed narodzeniem, okres niemowlęcy, dzieciństwo, młodość, życie dorosłe i dojrzałe aż po wiek starszy, senioralny. Życie to może się rozwijać w dwojaki sposób, lepszy lub gorszy; taki, który bardziej lub mniej odpowiada ludzkiemu dobrostanowi, przy czym nie chodzi tu jedynie o dobre samopoczucie, ale także o inne aspekty ludzkiego życia. Przy jego ocenie uwzględniane są wartości subiektywne oraz te, które $\mathrm{w}$ ramach cywilizacji zachodniej uchodzą za obiektywne. Te ostatnie mają znaczenie priorytetowe. Takich obserwacji ludzkiego życia dokonał między innymi św. Tomasz z Akwinu ${ }^{16}$. Zauważył on, że dynamika ludzkiej egzystencji nie ma charakteru jakiegoś nieuporządkowanego biegu zdarzeń. Jest to proces, który ma właściwy sobie cel, jakim jest osiągnięcie pewnej ludzkiej pełni, którą można określić jako ludzkie osobowe spełnienie ${ }^{17}$. Spełnienie to polega na harmonijnym rozwoju wszystkich potencjalności, czyli uzdolnień, jakimi dysponuje człowiek; Ewangelia nazywa je talentami. Potoczne rozumienie talentów nie zawsze odpowiada filozoficznym obserwacjom i konkluzjom: mając na myśli talenty, zwykle utożsamiamy je z jakimiś szczególnymi uzdolnieniami (np. w sztuce czy w sporcie). Tymczasem potencjalności (talenty), o których mowa w kontekście ludzkiego osobowego spełnienia, to typowe dla wszystkich ludzi zdolności, dzięki którym ludzkie życie się rozwija i zmierza ku swej pełni, w czym dużą rolę odgrywa harmonia tego rozwoju.

Człowiek ma różne uzdolnienia (potencjalności, możliwości): te, które służą jego indywidualnemu rozwojowi, i te, które służą jego zaangażowaniu w różnego rodzaju wspólnoty, z którymi mamy do czynienia w naszym życiu, np.: rodzinę, grupy rówieśnicze, szkołę, miejsce pracy, społeczności regionalne czy nawet państwo. $Z$ kolei uzdolnienia typu indywidualnego są dwojakiego rodzaju: jedne są wspólne wszystkim ludziom - mamy je tak samo jak każdy inny człowiek (wynikają one z naszego człowieczeństwa), natomiast drugi

${ }^{16}$ Kiedy przedstawia się poglądy filozoficzne św. Tomasza, napotkać można czasem pytanie: Co św. Tomasz, żyjący w XIII wieku mógł wiedzieć o problemach ludzi żyjących w XX czy XXI wieku? Za jego czasów o wielu dzisiejszych zagadnieniach ludzie nie mieli najmniejszego pojęcia. Rzecz w tym, że filozofia jest tą dziedziną nauki, która szuka prawidłowości najbardziej podstawowych. Te zaś, także w przypadku człowieka, nie zmieniają się zbyt często, a czasem nie zmieniają się w ogóle. Dlatego ujęcia filozoficzne nie tracą swej wartości pomimo upływającego czasu. Tym też uzasadnia się ponadczasowość filozoficznych obserwacji i stwierdzeń Platona, Arystotelesa czy św. Augustyna. Ta prawidłowość dotyczy także antropologii św. Tomasza. Cechą charakterystyczną nauk filozoficznych, odróżniającą je od nauk przyrodniczych, jest też inny sposób rozwoju tych pierwszych. W odróżnieniu od nauk przyrodniczych (zwanych też eksperymentalnymi lub pozytywnymi) przedmiot filozofii jest jej dany od razu w całości, podczas gdy w ramach nauk pozytywnych odsłania się on (rozwija się) stopniowo, w miarę nowych odkryć i obserwacji. Dlatego w filozofii nie ma takiego rozwoju i postępu ani takich zmian, jak w naukach przyrodniczych.

17 Zagadnienie to opisuje grupa nawiązujących do myśli św. Tomasza anglojęzycznych filozofów i teologów, takich jak: G. Grisez, J. Boyle, B. Cole. J. Finnis i inni (por. Grisez i in. 1983). 
rodzaj to te, które dana osoba ma w swej osobowej indywidualności i niepowtarzalności: takie talenty mieli np. Mickiewicz, Matejko czy Sienkiewicz, ale też ma je każdy z nas. W dążeniu do osobowego spełnienia chodzi o harmonijny rozwój obu rodzajów oraz wszystkich innych (a więc też indywidualnych i wspólnotowych) ludzkich potencjalności.

W ramach swego opisu ludzkiej kondycji św. Tomasz wyróżnił pewne dynamizmy, które są wspólne dla wszystkich ludzi i dla każdego z osobna. Pierwszym takim dynamizmem jest dążność do zachowania własnego jestestwa. Drugim - dążenie do zachowania własnego gatunku, trzecim - dążenie do życia w społeczności i czwartym - dążenie do poznania prawdy. Wszystkie te ludzkie dążenia mają właściwe sobie cele, które człowiek postrzega jako dobra, do których winien dążyć, co więcej, jako najważniejsze ludzkie dobra. I tak, pierwszym dobrem, zarazem najbardziej podstawowym, bo będącym podstawą wszelkich innych ludzkich dóbr, jest związane z zachowaniem własnego jestestwa, ludzkie życie ${ }^{18}$. Drugim dobrem jest małżeństwo i prokreacja, trzecim - tzw. społeczność, rozumiana jako zdolność do życia w różnego rodzaju wspólnotach i społecznościach, czwartym - prawda oraz znajomość Boga i Jego roli w ludzkim życiu.

Dalsze obserwacje pozwoliły dostrzec, że wymienione tu dobra nie stanowią jedynie czterech wyodrębnionych, pojedynczych dóbr, ale stanowią pewne grupy dóbr, gdzie głównemu dobru są podporządkowane inne, stanowiące jakby części składowe całej grupy. Przykładem może być dobro najbardziej podstawowe, jakim jest ludzkie życie, a dobrami składowymi i zarazem podporządkowanymi dobru głównemu (istnieje tu pewna hierarchia dóbr porządkowana przez dobro główne): zdrowie, integralność fizyczna, dobra kondycja zdrowotna, właściwy tryb życia, podejmowanie leczenia w sytuacji choroby, poprawne odżywianie się i wiele innych. W przypadku dążenia do zachowania gatunku dobrem głównym jest małżeństwo i prokreacja a dobrami składowymi są: miłość małżeńska, zdolność wymagania od siebie, cnota czystości (zarówno przedmałżeńskiej, jak i małżeńskiej), wierność małżeńska, czyli to wszystko, co sprzyja dobremu, szczęśliwemu pożyciu małżeńskiemu i rodzinnemu oraz przekazowi ludzkiego życia i jego rozwojowi.

Podobnie są ukonstytuowane pozostałe podstawowe dobra, które również funkcjonują jako określone grupy dóbr $\mathrm{z}$ dobrem podstawowym jako najważniejszym ${ }^{19}$. Osiągnięcie i zachowanie oraz rozwój dobra nadrzędnego (życia,

18 Mówiąc, że życie fizyczne człowieka jest dobrem najbardziej podstawowym, należy dodać, że w całej skali ludzkich dóbr nie jest ono jednak dobrem największym. Dobrem największym jest dobro całościowe osoby, któremu czasem można i należy poświęcić dobro ludzkiego życia. Przykładem takiej sytuacji jest męczeństwo.

19 We współczesnej teologii katolickiej istnieją dwie główne konkurujące ze sobą interpretacje nauki św. Tomasza dotyczące wspomnianych tu podstawowych dóbr ludzkich. Interpretacja znana 
małżeństwa i prokreacji, społeczności i prawdy wraz z poznaniem Boga) nie jest możliwe albo staje się bardzo utrudnione bez uwzględnienia dóbr podporządkowanych (owych dóbr składowych). Z kolei osiągnięcie osobowego spełnienia, zwłaszcza w jego dojrzałym kształcie, staje się niemożliwe bez osiągnięcia i partycypacji w owych podstawowych ludzkich dobrach. Tak więc mamy tu do czynienia z pewnymi bardzo ścisłymi i konsekwentnymi zależnościami: celem ludzkiego życia jest osobowe spełnienie; to spełnienie jest niemożliwe bez osiągnięcia pewnych podstawowych ludzkich dóbr (partycypacji w nich), a tych z kolei nie można osiągnąć, zachować i rozwinąć, jeśli niweczy się ich dobra składowe. W ten sposób niszczenie lub stawianie przeszkód na drodze do osiągnięcia podstawowych ludzkich dóbr staje się działaniem uniemożliwiającym lub poważnie utrudniającym osiągnięcie celu ludzkiego życia, jakim jest osobowe spełnienie. Dzięki osobowemu spełnieniu człowiek jako osoba coraz bardziej się staje, jest coraz bardziej sobą, coraz bardziej jest i staje się człowiekiem. Człowiek staje się lepszy poprzez stawanie się coraz bardziej człowiekiem, czyli tym, kim według Bożego planu ma być. To jest jego podstawowe zadanie życiowe: być coraz bardziej sobą, coraz bardziej być człowiekiem, zmierzać ku pełni swego człowieczeństwa, która czyni jego życie coraz doskonalszym, szczególnie w wymiarze etycznym (por. Kraj 2010, s. 223-240).

Zamieszczony powyżej opis ludzkiego życia i funkcjonujących w nim mechanizmów należy do realistycznego, a zarazem obiektywnego ujęcia rzeczywistości, czyli takiego, który opisuje rzeczywistość i wartości jako istniejące niezależnie od nas. Odniesienia do takiego właśnie ujęcia znajdujemy w licznych wytworach kultury, nie tylko zachodniej. Zauważamy więc, że przedstawiony tu opis dążeń właściwych człowiekowi (każdemu człowiekowi) jest wyrazem powszechnego ludzkiego doświadczenia, które od zawsze było sposobem weryfikacji twierdzeń o charakterze rozumowym, czyli filozoficznym, a więc także i etycznym (por. Huber 1994, s. 29-32) ${ }^{20}$. Mamy tu do czynienia z etycznym ujęciem ludzkiej kondycji. Zanim jednak opis ten zostanie wykorzystany jako podstawa i uzasadnienie dla powinności moralnych, należy jeszcze zwrócić uwagę na dwa zagadnienia.

Mamy dwa rodzaje etyki: etykę opisową i etykę normatywną. Etyka opisowa opisuje ludzkie zachowania takimi, jakie one są, skąd wynikają, jaka jest bądź może być ich podstawa. Etyka ta, opisując ludzkie wybory, pokazuje jednocześnie, które wybory dominują w danej społeczności, a których jest mniej.

jako szkoła dominikańska (która wymienia tu tzw. dobra dla osoby) oraz interepretacja szkoły anglo-amerykańskiej, która mówi o podstawowych ludzkich dobrach (basic human goods). Prezentację obu stanowisk i dyskusję pomiędzy nimi można znaleźć m.in. w: Ashley 1994, s. 68-96; George 1994 oraz Hittinger 1987.

${ }^{20}$ Etyka to inaczej filozofia moralna. 
Rodzi to pokusę, by owe wybory dominujące hic et nunc uznać za normę. Na podstawie tych danych często $\mathrm{w}$ mass mediach i w polityce toczone są batalie, by skłonić ludzi do uznania pewnych rozwiązań za najlepsze dla nich, a osiągnięcie odpowiedniej liczby zwolenników uważa się za sukces medialny i polityczny. Dużo rzadziej uwagę ludzi mediów i polityków zaprząta pytanie o dobro lub zło proponowanych zachowań ${ }^{21}$.

Etyka normatywna natomiast mówi nam o normie (powinności), czyli co należy czynić, jakich wyborów dokonywać, a jakich unikać, by osiągnąć główny cel ludzkiego życia (a także cele cząstkowe, pośrednie, będące etapami na drodze do celu głównego). Etyka chrześcijańska w części, jaką większość ludzi w Polsce zna, a więc głównie ze swej formacji katechetycznej i podejmowanych dyskusji medialnych, jest etyką normatywną. Mówi nam ona, co mamy czynić i czego unikać, by osiągnąć cel ludzkiego życia: osobowe spełnienie (por. Grisez 1983, s. 807-827) ${ }^{22}$.

Ponadto etyka chrześcijańska zwraca uwagę na dwa ważne i uzupełniające się wymogi nawiązujące do greckiej tradycji filozoficznej i etycznej. Pierwszy z nich mówi o tym, że dana norma (powinność), jeśli ma charakter etyczny, to winna dotyczyć wszystkich ludzi, którzy znaleźli się w takiej samej sytuacji moralnej, w takich samych okolicznościach. Drugi wymóg natomiast wspomina o konieczności stosowania się samego etyka do głoszonej przez niego powinności. Znamy bowiem $\mathrm{z}$ historii (także ostatniej) różnego rodzaju pseudoetyczne powinności, głoszone przez promotorów różnych ideologii, którzy nakładali je na innych ludzi, a sami czuli się zwolnieni z ich wypełniania. Przykładem może być tzw. „etyka” komunistyczna, wymagająca od członków klasy robotniczej dużych nieraz wyrzeczeń, podczas gdy głoszący te wymogi członkowie partii komunistycznej nie stosowali tych zasad do siebie, opływając we wszelkiego rodzaju dobra. Przykładem bardziej współczesnym podobnej aberracji etycznej jest postać prominentnego bioetyka utylitarystycznego Petera Singera, który głosił potrzebę wstrzymania pomocy i opieki oraz doprowadzenia do śmierci ludzi w ciężkich i nieuleczalnych chorobach. Gdy jednak taka choroba dosięgła jego matkę, jako pierwszy starał się zapewnić jej jak najlepsze warunki opieki ${ }^{23}$. Są to bardzo ważne spostrzeżenia dotyczące krytyków nauki moralnej Kościoła, ponieważ można wśród nich znaleźć na-

${ }^{21}$ Tendencję taką można także zauważyć w podejściu niektórych teologów, co oczywiście trudno zaaprobować. O zjawisku tym pisze m.in. ks. M. Machinek (Machinek 2018, s. 24).

22 Spełnienie to ma dwie postaci: jedną w ramach ziemskiej egzystencji i drugą, ostateczną, w ramach komunii z Bogiem w wieczności. Ziemska postać osobowego spełnienia jest koniecznym etapem na drodze ku ostatecznej formie osobowego spełnienia się człowieka.

${ }^{23}$ Por. P.J. Colosi, What's Love Got to Do With It? The Ethical Contradictions of Peter Singer, https://oldarchive.godspy.com/issues/WHATS-LOVE-GOT-TO-DO-WITH-IT-The-Ethical-Contra dictions-of-Peter-Singer-by-Dr-Peter-J-Colosi.cfm.htm, [dostęp: 30.08.2019]. 
śladowców tak komunistów, jak i P. Singera. Przykładem mogą być zwolennicy ideologii LGBT, którzy, głosząc potrzebę tolerancji chrześcijan wobec siebie, nie mają najmniejszego zamiaru zachować tolerancji wobec chrześcijan.

\section{Propozycje moralne odrzucane przez Kościół na przykładzie in vitro}

Przedstawienie sposobu, w jaki Kościół uzasadnia swoje stanowisko moralne, nie byłoby pełne bez jakiegoś przykładu. Chodzi w nim o pokazanie, jak na podstawie danych rozumowych można wykazać niemoralność IVF. Literatura etyczna dotycząca tego zagadnienia jest bardzo obszerna. Mając tego świadomość, na potrzeby tego krótkiego opracowania zostały wybrane jedynie pewne, najczęściej występujące argumenty. W każdym innym przypadku przyjęty sposób rozumowania będzie jednak podobny, niezależnie od tego, jakiej propozycji moralnej i jakich ludzkich dóbr będzie on dotyczył24.

Dlaczego Kościół odrzuca IVF? Czy może nie chce szczęścia małżonków pragnących potomstwa? Czy dlatego, że boi się nowego, bo będąc konserwatywny, trwa przy starych, dziś już niezrozumiałych i zdezaktualizowanych zasadach, nie dopuszczając myśli o tym, że świat się zmienia? Najpierw kilka słów o samym IVF. Wbrew rozmaitym doniesieniom medialnym (w wielu przypadkach podającym nieprawdziwe lub zmanipulowane dane) IVF jest metodą o małej sprawności, która pomimo upływu wielu lat znacząco się nie poprawiła. Zapłodnienie in vitro jest (zasadniczo) stosowane w przypadku niepłodności ${ }^{25}$. Polega ono na pobraniu gamet od rodziców przyszłego dziecka i połączeniu ich w laboratorium (pozaustrojowo), a następnie przeniesieniu tak powstałego embrionu do organizmu matki. Ponieważ nie wszystkie gamety chcą się połączyć ze sobą, stosuje się różne metody, by takiego połączenia dokonać. Mamy tu więc do czynienia z przełamywaniem biologicznych barier, co często wiąże się z komplikacjami: powstały embrion albo nie przeżywa (na różnych etapach swego rozwoju, także płodowego), albo wynikiem takiego połączenia są różnego rodzaju zaburzenia i choroby przyszłego człowieka. Wiele spośród embrionów, a potem płodów nie przeżywa także $\mathrm{z}$ powodu specyficznych procedur około IVF (diagnoza preimplantacyjna, zamrażanie

${ }^{24} \mathrm{~W}$ tej części chodzi o wyjaśnienie, dlaczego rozum, którym człowiek kieruje się w swym postępowaniu moralnym, dokonuje takich, a nie innych wyborów. Należy tu podkreślić, że nieznajomość tychże uzasadnień nie przesądza o niemożności dokonania poprawnego wyboru moralnego. Por. pkt 1 tego opracowania.

${ }^{25}$ Jest to także możliwe w przypadku osoby robiącej błyskotliwą karierę, która nie chcąc jej przerywać, a pragnąc potomstwa, korzysta z tej techniki i tzw. macierzyństwa zastępczego. W ten sposób poczyna się i przychodzi na świat także potomstwo par homoseksualnych (zwłaszcza gejowskich). 
embrionów czy tzw. redukcja embrionalna, czyli selektywna aborcja rozwijających się płodów) ${ }^{26}$.

Ze względu na niską sprawność tej metody często zapładnia się większą liczbę komórek jajowych (tworzy się więcej niż jeden embrion) ${ }^{27}$, by procedurę implantacji embrionu do organizmu matki można było powtórzyć, gdy za pierwszym czy za kolejnym razem coś w rozwoju nowego człowieka się nie powiedzie. Bywa jednak, że procedura się uda za pierwszym (lub kolejnym) razem i wtedy te dodatkowe embriony nie są już ,potrzebne”, stając się tzw. embrionami nadliczbowymi. Zwykle się je zamraża w ciekłym azocie, by następnie wykorzystać dla innych par lub do eksperymentów medycznych. Ze względu na ich ogromną liczbę (dziesiątki tysięcy w skali jednego państwa) ${ }^{28}$ po przepisanym prawem okresie przechowywania embriony te się uśmierca. Przed upływem tego czasu embriony te traktuje się jak rzeczy: sprzedaje się je, wykorzystuje do doświadczeń medycznych lub jako materiał biologiczny (np. jako źródło embrionalnych komórek macierzystych), mówi się o nich w kategoriach czyjejś własności.

Nawet tak pobieżny opis tego, co dzieje się w ramach IVF, pozwala domyślać się, że Kościół nie będzie się zgadzał na taki sposób rozwiązywania problemów ludzkiej płodności. Jednak ten brak aprobaty, będący wyrazem reakcji prawego ludzkiego sumienia, nie ma charakteru arbitralnego. Uzasadnieniem owej dezaprobaty jest naruszanie lub wprost niszczenie podstawowych ludzkich dóbr w ramach procedury IVF.

Życie ludzkie rozpoczyna się w momencie poczęcia. Nie jest to stwierdzenie o charakterze filozoficznym ani teologicznym, lecz biologicznym ${ }^{29}$. Pierwszym etapem ludzkiego rozwoju jest embrion ${ }^{30}$. Status ludzkiego embrionu jest jednak zupełnie różny od statusu embrionu jakiejkolwiek innej istoty żyjącej. W pierwszym przypadku mamy do czynienia z człowiekiem, z osobą ludzką (chociaż jeszcze nie w pełni ukształtowaną, będącą u początku swojego rozwoju), która ma wielką wartość wsobną (wyrażaną współcześnie za pomocą pojęcia ,godności”) i której przysługują wszystkie ludzkie prawa, znane także jako prawa człowieka. Odnoszą się one do pewnych wartości, przysługują-

${ }^{26}$ Internet jest pełen informacji o możliwych komplikacjach związanych z IVF. Wystarczy wpisać do wyszukiwarki: „complications of IVF”, by się o tym przekonać.

27 Także tu są wyjątki (por. Kraj 2008, s. 108-109).

28 Por. A. Moressi, Procreazione assistita. Embrioni congelati, la città dimenticata, https:// www.avvenire.it/famiglia-e-vita/pagine/embrioni-congelati-la-citt-dimenticata [dostęp: 26.08.2019].

29 Paradoksalnie to właśnie zapłodnienie in vitro pokazało, że ludzki embrion, nowe ludzkie życie, rozwija się (do pewnego etapu) poza organizmem matki. Nie jest więc częścią tego organizmu, o czym często nie chcą pamiętać zwolennicy aborcji.

30 Jest nim embrion jednokomórkowy nazywany też zygotą, który w wyniku podziałów komórkowych i rozwoju osobniczego przekształca się najpierw w embrion wielokomórkowy, a potem w płód. 
cych każdej osobie ludzkiej. Wśród nich najważniejsze miejsce zajmują podstawowe ludzkie dobra ${ }^{31}$. Jeśli więc stawia się pytanie o możliwość akceptacji IVF, to odpowiedź na nie wynika z odpowiedzi na inne, wcześniejsze pytanie: co w wyniku tej procedury dzieje się z podstawowymi ludzkimi dobrami?

Pierwszym i najbardziej podstawowym dobrem jest dobro ludzkiego życia, które obejmuje także integralność fizyczną i zdrowie. W przypadku IVF mamy do czynienia z działaniem, którego wynikiem jest śmierć wielu ludzkich osób w najwcześniejszym etapie ich życia i rozwoju ${ }^{32}$. Także inne działania związane z IVF naruszają integralność fizyczną embrionu, np. pobranie komórek embrionu do diagnozy preimplantacyjnej lub do doświadczeń. Ludzkie zdrowie również jest narażane w czasie i w wyniku tej procedury, czego wyrazem są wspomniane wyżej defekty i komplikacje zdrowotne. Bardzo częstym efektem stosowania procedury IVF jest więc niszczenie i/lub narażanie na poważny uszczerbek tak podstawowego ludzkiego dobra, jakim jest życie embrionu oraz jego integralność fizyczna i zdrowie, stanowiące integralną część dobra ludzkiego życia.

Bywa jednak, że w ramach procedury IVF nie powstają embriony nadliczbowe. Może powstać tylko jeden embrion, który następnie zostaje zaimplantowany do łona matki i przychodzi na świat nowy człowiek. Czy wtedy, wobec faktu, że nie ginie żaden człowiek i że nie ma żadnego uszczerbku na zdrowiu (por. Kraj 2008, s. 108-109), można by zaakceptować tę procedurę? Odpowiedź na to pytanie jest również negatywna i również nie dlatego, że szuka się przysłowiowej „dziury w całym”. Jest tak dlatego, że w grę wchodzą tu także inne dobra, nie tylko samo ludzkie życie, integralność fizyczna czy zdrowie.

Niegdyś etycy nie zastanawiali się nad konstytutywnymi elementami małżeństwa oraz procesu wydania na świat potomstwa tak, jak robią to dziś. Nie było wtedy IVF i nie było potrzeby jak dziś zastanawiania się nad najważniejszymi czynnikami związanymi z przekazem ludzkiego życia. Wiemy, że prawo naturalne mówi „nie!” wobec propozycji IVF. Zastanawiamy się więc, dlaczego to prawo tak mówi. Co jest złego w pragnieniu potomstwa przez małżonków, zwłaszcza w sytuacji, gdyby byli oni związani sakramentalnym węzłem małżeńskim? Jeśli można korzystać z pomocy medycyny w tylu innych sytuacjach, to dlaczego nie można po nią sięgąć w przypadku niepłod-

31 Okazuje się, że prawa człowieka odnoszą się do tych samych dóbr, które warunkują osobowe spełnienie się człowieka.

32 Nie mogąc się inaczej uporać z tym złem, wielu ludzi zaangażowanych w procedurę zapłodnienia in vitro ,radzi sobie" z tym problemem, odmawiając ludzkim embrionom statusu osobowego albo wręcz człowieczeństwa. Jest rzeczą bardzo ciekawą, że tylko w przypadku ludzkiego embrionu padają stwierdzenia, iż embrion ten to nie jest człowiek. Nie spotyka się natomiast podobnych stwierdzeń w przypadku zwierząt, na przykład że embrion małpy to nie jest małpa. Na temat określeń zastępczych mających deprecjonować rzeczywistą wartość ludzkiego embrionu a usprawiedliwiać zapłodnienie in vitro (por. Kraj 2008, s. 109-111). 
ności? Okazuje się jednak, że można skorzystać z pomocy medycyny także w przypadku niepłodności, lecz nie można wykorzystać każdej propozycji, która pada ze strony lekarza. Pytanie o moralną dopuszczalność IVF, gdy zachowane byłyby dobra ludzkiego życia, jego integralności i zdrowia, jest więc pytaniem o inne podstawowe ludzkie dobra naruszane $\mathrm{w}$ ramach procedury zapłodnienia in vitro.

W grę wchodzi tu dobro małżeństwa, a także związana z tym dobrem godność dziecka, które w tym małżeństwie się poczyna. Przekaz ludzkiego życia nie jest działaniem etycznie obojętnym. Życie można bowiem przekazać w różny sposób, na przykład w wyniku gwałtu. Nikt (żaden człowiek dobrej woli) jednak tego nie pochwala ani nie zaleca, ponieważ istnieje powszechne przekonanie moralne, że taki sposób jest wysoce niegodziwy i przez to niemożliwy do moralnej akceptacji. Stosowanie brutalnego przymusu nie jest jedynym niegodziwym sposobem przekazu ludzkiego życia. Swego czasu Niemcy wpadli na pomysł ,hodowli” czystych rasowo ludzi w ramach instytucji zwanej Lebensborn. Właściwie nie było tu przymusu, nie było też zastosowanych żadnych technicznych środków, a jednak w powszechnej ocenie nie był to właściwy sposób przekazu ludzkiego życia ${ }^{33}$.

Nie jest celem tego opracowania wymienianie wszystkich możliwych anomalii związanych z przekazem ludzkiego życia, natomiast przywołanie ostatnich dwóch przykładów ma na celu pokazanie, że nie jest wszystko jedno, jak to się dokonuje; i że jest to powszechne ludzkie przekonanie moralne, które nie zmienia się pomimo, zwykle podejmowanych ad hoc, prób przekonywania, że jest inaczej. Za każdym razem, gdy spotykamy się z propozycją sprzeczną ze sposobem uznanym za w pełni etyczny, powstaje pytanie, czego zabrakło lub czego nie powinno tu byćc ${ }^{34}$. Te same pytania stawiamy w przypadku zapłodnienia in vitro. Pierwsze z nich brzmi: Jaki jest w pełni etyczny sposób przekazu ludzkiego życia?

$\mathrm{W}$ pełni etyczny sposób ma miejsce w ramach małżeństwa, a więc jest działaniem męża i jego żony. Powinno to być działanie inspirowane ich wzajemną miłością, a dziecko winno być owocem ich pełnego miłości zjednoczenia. Poczęcie dziecka winno być owocem aktu małżeńskiego, będącego wyrazem miłości małżonków. Akt taki ma charakter osobowy: mąż traktuje żonę jak drugą osobę i vice versa. Także dziecko, którego życie się rozpoczyna, jest przez nich traktowane jako osoba, czyli jako im równe w swej godności. Jest przez nich postrzegane jako osobowy dar im dany, jako ich życiowe zadanie,

${ }^{33}$ VS, wiki, Fabryka czystych rasowo ludzi. Horror w domu surogatek Hitlera, https://www.fakt. $\mathrm{pl} /$ wydarzenia/swiat/lebensborn-fabryka-dzieci-esesmanow/hfs44wh\#slajd-2, [dostęp: 26.08.2019].

34 Dotyczy to także tych sytuacji, które najczęściej mają miejsce, a które dotyczą obopólnej zgody kochanków, co wywołuje liczne i nieraz tragiczne w skutkach konflikty, o których mówi się nie tylko w literaturze pięknej. 
które mają do wypełnienia ${ }^{35}$. Nie jest więc środkiem do zaspokojenia ich ambicji lub oczekiwań, ponieważ miłość wyklucza traktowanie drugiego człowieka wyłącznie lub przede wszystkim jako środek do jakiegoś innego celu.

Co natomiast dzieje się w ramach IVF? Przede wszystkim poczęcie nowego człowieka nie jest dziełem rodziców. Dostarczają oni jedynie materiał biologiczny, ponieważ tego wymaga techniczna procedura, której w różnym stopniu są podporządkowane działania wszystkich zainteresowanych stron. $\mathrm{Na}$ razie, na obecnym etapie rozwoju biotechnologii bez gamet od obu biologicznych rodziców nowe życie raczej nie powstaje, dlatego potrzebny jest udział obydwojga rodziców ${ }^{36}$; jednak w ramach IVF nowe życie nie powstaje w wyniku osobowego aktu rodziców, lecz wskutek manipulacji, czyli działania o charakterze rzeczowym, którego dokonuje osoba spoza małżeństwa - lekarz (lub osoba o pokrewnych kompetencjach) w laboratorium. Należy podkreślić, że w takim przypadku aktu poczęcia (aktu generatywnego) nie dokonują tu małżonkowie, chociaż akt taki im wyłącznie jest zastrzeżony, tylko im przysługuje (i nie mogą oni tego aktu scedować na nikogo innego). W przypadku IVF nie mamy do czynienia z aktem miłości małżeńskiej, który ma wymiar osobowy. Zapłodnienie in vitro to akt rzeczowy i umieszczenie początków nowego życia w tym kontekście sprawia, że to nowe życie, nowy człowiek, jest traktowany jak rzecz, co z kolei ułatwia wiele innych ,rozwiązań”37, takich jak: selekcja embrionów przed implantacją, ich zamrażanie, skazywanie na eksperymenty, których nie przeżywają, podejście typu: jeśli ten nie będzie odpowiedni, to się go wymieni na inny, zastąpi innym - słowem: nowy człowiek nie jest traktowany jako niepowtarzalna osoba, będąca sama w sobie celem działania jego rodziców, lecz jest wyłącznie albo przede wszystkim środ-

\footnotetext{
${ }^{35} \mathrm{Nie}$ jest traktowane jako intruz, który im przeszkadza lub będzie przeszkadzał i dlatego należy się przed nim bronić lub się go pozbyć - to odpowiedź na pytanie status przyznawany nasciturusowi $\mathrm{w}$ kontekście antykoncepcji i aborcji.

${ }^{36}$ Można sobie jednak coś takiego wyobrazić w ramach prób „przeprogramowania” ludzkich komórek macierzystych. Por. Y. Lee, E. Kang, Stem cells and reproduction, http://www.bmbreports. org/journal/view.html?uid=1400\&vmd=Full\& [dostęp: 17.12.2019].

37 Konsekwencje nieosobowego traktowania ludzi można zobaczyć na drastycznym (lecz dobrze to ilustrującym) przykładzie z historii: „Pierwszą torturą w obozach koncentracyjnych nie było bicie i głodzenie więźniów, lecz pozbawianie ich godności. Pozbawianie godności polegało na odebraniu im imienia i nazwiska, czyli traktowaniu ich nie jako niepowtarzalnych osób, lecz jako powtarzalnych numerów. To przede wszystkim decydowało o tym, co działo się z nimi później. Ponieważ jeden numer można było zastąpić innym, dlatego niczyje życie nie było drogocenne z racji jego osobowej niepowtarzalności. Takie traktowanie osób słusznie osądzono jako zbrodnię przeciw ludzkości. Jeśli ludzki embrion można potraktować jak rzecz, to można z nim potem uczynić to wszystko, co ludzie czynią z rzeczami - i to się właśnie dzieje w kontekście zapłodnienia in vitro. Trzeba zaznaczyć, iż ani więźniowie ani ludzkie embriony obiektywnie nie stają się numerami lub rzeczami: są jedynie tak traktowani, jakby nimi byli". Taka forma zła otwiera jednak furtkę dla innych jego form: zranienia i/lub zabicia niewinnego człowieka. (Kraj 2008, Manuskrypt artykułu w dyspozycji autora, s. 9).
} 
kiem do zaspokojenia ich pragnień (skądinąd dobrych, lecz cel nie uświęca środków); jest traktowany jako powtarzalna rzecz, którą łatwo można zastąpić inną. To jest właśnie rzeczywistość IVF.

„Nie!” Kościoła, ale i wielu przyzwoitych ludzi wobec IVF nie wynika więc $\mathrm{z}$ ich niechęci wobec postępu medycyny lub z jakichś trudno zrozumiałych a bezdusznych racji. Jest skutkiem refleksji nad wymogami prawa naturalnego, które zabrania korzystania z tego rodzaju „leczenia”, bo jego efektem jest śmierć i/lub zranienie drugiego człowieka. Tym efektem jest także podeptanie godności dziecka i jego praw, zwłaszcza praw do poczęcia się i urodzenia na sposób godziwie ludzki, czyli jako owoc miłości własnych rodziców. Owe naruszenia powodują także problemy w życiu samych małżonków. Poczęcie dziecka, niebędące wynikiem działania małżonków, lecz osoby spoza małżeństwa, nie jest wcale zgodne ze strukturą i funkcjonowaniem tego związku i może powodować jego poważne osłabienie. W ten sposób skutki korzystania $\mathrm{z}$ omawianej procedury naruszają także inne dobra wymieniane jako podstawowe ludzkie dobra: dobro społeczności (poprzez naruszenie więzi małżeńskich) oraz dobro więzi z Bogiem, którego prawo (w postaci prawa naturalnego) jest tutaj poważnie naruszone.

Zapłodnienie in vitro jako propozycja dla niepłodnych małżeństw spotyka się z dezaprobatą Kościoła. Wbrew wielu krytykom nie jest to stanowisko opierające się na przesądach i uprzedzeniach lub na jakimś cywilizacyjnym zacofaniu. Jest ono, jak w każdym innym przypadku, stanowiskiem przejrzyście uzasadnionym i dlatego łatwym do zrozumienia. Fakt, iż nie każdy i nie od razu wie, dlaczego jest ono właśnie takie, a nie inne, nie oznacza, że opiera się ono na jakichś trudnych do zrozumienia lub tajemniczych racjach. Każdy moralnie uczciwy człowiek, stając wobec propozycji IVF, wie, że jest ona zła; że nie powinien z niej korzystać. To, że nie od razu uświadamia sobie, dlaczego sumienie mu tak mówi, nie oznacza, że nie będzie w stanie tego zrozumieć. Problem w tym, że nie każdy jest etykiem, znawcą zagadnień dotyczących ludzkiego postępowania moralnego. Jednak bliższe zapoznanie się z uzasadnieniem funkcjonującym w ramach katolickiej etyki, pozwala się upewnić co do prawości zajmowanego przez Kościół stanowiska i własnych decyzji moralnych.

Przeszkodą na tej drodze jest na pewno fakt, iż w wielu przypadkach, zanim się to stanie (zanim człowiek zrozumie poprawność wskazań Kościoła), na jego drodze stają liczni przeciwnicy moralnego nauczania Kościoła, którzy dysponując potężnymi środkami przekazu, są w stanie wytworzyć fałszywe przekonanie co do rzeczywistych racji stojących za stanowiskiem pasterzy Kościoła. 
Opracowanie to wychodzi naprzeciw trudnościom ze zrozumieniem i przyjęciem nauki moralnej Kościoła, by na przykładzie takiej właśnie kontrowersyjnej moralnie propozycji ukazać, jak funkcjonuje moralność: skąd wiemy, że nie należy dokonywać pewnych wyborów, dlaczego takich wyborów nie należy dokonywać oraz w jakiej kolejności się to dzieje; że brak znajomości argumentów z zakresu etyki i antropologii nie zwalnia człowieka z odpowiedzialności za podejmowane przezeń wybory moralne, co do których sumienie wyraźnie go informuje, że jest to zły wybór. Jednocześnie, odwołując się do argumentów rozumowych, a więc dostępnych dla każdego człowieka dobrej woli, opracowanie to pokazuje, jak Kościół uzasadnia swe stanowisko moralne ${ }^{38}$. Przywołuje ono podstawowe ludzkie dobra, utożsamiane $\mathrm{z}$ tzw. wartościami chrześcijańskimi, których naruszenie jest działaniem przeciw człowiekowi i przeciwko Bogu, Jego Stwórcy i Zbawcy. Do tego utożsamienia: wartości chrześcijańskie - podstawowe ludzkie dobra, warunkujące spełnienie się człowieka, które jest w pewnym sensie sumą owych dóbr oraz celem ludzkiego życia, może się odwołać każdy wyznawca Chrystusa, stający wobec pytania, dlaczego będąc chrześcijaninem, nie może się zgodzić na niektóre propozycje spotykane w przestrzeni publicznej. Owa zależność: wartości chrześcijańskie - podstawowe ludzkie dobra - osobowe spełnienie człowieka - cel ludzkiego życia odnosi nas także do innej relacji, która wiele wyjaśnia: celem ludzkiego życia jest rozwój własnego człowieczeństwa - to, by bardziej człowiekiem być, bo dobro jest w pełni bycia. Dlatego zestawiając ową relację z wymienionymi wyżej utożsamieniem i zależnością, zaczynamy dostrzegać, jak tzw. wartości chrześcijańskie uczestniczą w naszym człowieczeństwie i zarazem warunkują je, jego pełnię, czyli obiektywny i najbardziej podstawowy cel naszego życia, wszystkich naszych wyborów, działań i powinności. W ten sposób, nawet nie znając dokładnie konkretnego rozstrzygnięcia moralnego, ale znając sposób rozumowania, jego logikę, nie jesteśmy zupełnie bezbronni wobec argumentów tych, którzy z Kościołem się nie zgadzają (także spośród jego członków). Dzięki tej wiedzy możemy nie tylko bronić „wartości chrześcijańskich”, ale możemy to robić w pełni świadomie i skutecznie.

${ }^{38}$ Należy tu jednak ciągle pamiętać o misji Kościoła i jego pasterzy. Por. przypis 8 tego opracowania. 


\title{
HOW DOES MORALITY WORK? CHRISTIAN MORAL CHOICES AND CHRISTIAN VALUES
}

\begin{abstract}
SUMMARY
Knowledge of the moral teaching of the Roman Catholic Church is generally scarce, even among believers. This situation contributes to numerous misunderstandings concerning the Church's position within the public debates of new proposals like IVF or sexual morality (eg. the LGBT movement). It seems to outsiders that the Church's standpoint is based on some old and outdated convictions incomprehensible for people today. Meanwhile for the Church, which is concerned with the overall wellbeing of each man, this well-being is the main reason for its viewpoint and teaching. Although the Church's explanation is not based exclusively on philosophical reasons (i.e. based on human reason and thus intelligible for all people of good will) these reasons play an important role in the dialogue between the Church and the contemporary world. One of the Church's most important rationales refers to the concept of human personal fulfilment and basic human goods.
\end{abstract}

Keywords: human being; moral choice - description; moral choice - justification; natural law; moral teaching of the Church; human personal fulfilment; basic human goods

Słowa kluczowe: człowiek; wybór moralny - opis; wybór moralny - uzasadnienie; prawo naturalne; moralne nauczanie Kościoła; ludzkie osobowe spełnienie; podstawowe ludzkie dobra

\section{BIBLIOGRAFIA}

Abbà G. (2003), Esame epistemologico della teologia morale di San Tommaso d'Aquino, w: Quale filosofia in teologia morale? Problemi, prospettive e proposte, red. P. Carlotti, Roma.

Ashley B.M. (1994), What is the End of the Human Person? The Vision of God and Integral Human Fulfillment, w: Moral Truth and Moral Tradition: Essays in Honor of Peter Geach and Elisabeth Anscombe, red. L. Gormally, Dublin, s. 68-96.

George R.P. red. (1994), Natural Law Theory. Contemporary Essays, Oxford.

Grisez G. et al. (1983), The Way of the Lord Jesus, Vol. One, Christian Moral Principles, Chicago.

Hittinger R. (1987), A Critique of the New Natural Law Theory, Notre Dame.

Huber C. (1994), Limiti della validità del sapere scientifico, w: Lineamenti di etica della sperimentazione clinica, red. A.C. Spagnolo, C. Huber, Milano, s. 29-38.

Kania D. (2019), Zniszczyć cywilizację, „Gazeta Polska” \#31 (1355) 31/07, s. 6-9.

Kraj T. (2008), Wokót dyskusji na temat zaptodnienia in vitro, „Teologia i Moralność” 4, s. 107-118. 
Kraj T. (2010), Granice genetycznego ulepszania człowieka, Kraków.

Machinek M. (2018), Przesłanie Humanae vitae z perspektywy pięćdziesiątej rocznicy ogłoszenia encykliki, ,Teologia i Moralność” 2, s. 13-27.

May W. (2003), Introduction to Moral Theology, Huntington.

Mroczkowski I. (2011), Teologia moralna. Definicja. Przedmiot. Metoda, Płock.

Nykiel M. (2019), Operacja ,Biatystok”, „Sieci” Nr 30 (348), s. 22-25.

Pinckaers S.Th. (1999), The Place of Philosophy in Moral Theology, w: Faith and reason: The Notre Dame symposium 1999, red. T.L. Smith, The Maritain Center, United States, s. 10-20.

Rhonheimer M. (1994), La prospettiva della morale. Fondamenti dell'etica filosofica, Roma.

Publikacje internetowe

Anon, Benedykt XVI skomentowat reakcje na jego tekst o przyczynach pedofilii w Kościele, https:// www.tvp.info/44116463/benedykt-xvi-skomentowal-reakcje-na-jego-tekst-o-przyczynachpedofilii-w-kosciele, [dostęp: 30.08.2019].

Anon, Senator Pociej o abpie Jędraszewskim i "tęczowej zarazie": Jako głos PO mówię, że to skandaliczne słowa, http://www.tokfm.pl/Tokfm/7,103087,25053883,senator-pociej-a-abp-jedraszew skim-i-teczowej-zarazie-jako.html [dostęp: 27.08.2019].

Colosi P.J., What's Love Got to Do With It? The Ethical Contradictions of Peter Singer, https://oldar chive.godspy.com/issues/WHATS-LOVE-GOT-TO-DO-WITH-IT-The-Ethical-Contradictionsof-Peter-Singer-by-Dr-Peter-J-Colosi.cfm.htm [dostęp: 30.08.2019]

Lee Y., Kang E., Stem cells and reproduction, http://www.bmbreports.org/journal/view.html?u $\mathrm{id}=1400 \& \mathrm{vmd}=$ Full\& [dostęp: 17.12.2019].

Moressi A., Procreazione assistita. Embrioni congelati, la città dimenticata, https://www.avvenire. it/famiglia-e-vita/pagine/embrioni-congelati-la-citt-dimenticata [dostęp: 26.08.2019].

VS, wiki, Fabryka czystych rasowo ludzi. Horror w domu surogatek Hitlera, https://www.fakt.pl/wy darzenia/swiat/lebensborn-fabryka-dzieci-esesmanow/hfs44wh\#slajd-2 [dostęp: 26.08.2019].

Tomasz Kraj - kapłan archidiecezji krakowskiej, dr hab. teologii i profesor Uniwersytetu Papieskiego Jana Pawła II w Krakowie, kierownik Katedry Teologii Życia na Wydziale Teologicznym UPJP II. Obszary badawcze: bioetyka, genetyka $\mathrm{z}$ perspektywy etycznej, prawo naturalne, etyka cnoty. 